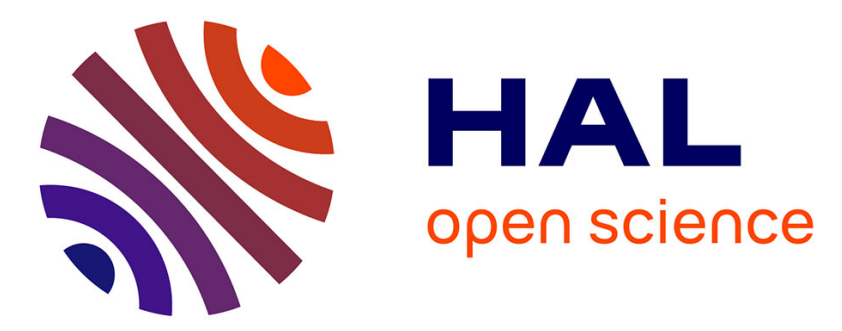

\title{
Posaconazole salvage treatment in paediatric patients: a multicentre survey
}

\author{
T. Lehrnbecher, A. Attarbaschi, M. Duerken, J. Garbino, B. Gruhn, U. \\ Kontny, S. Lüer, R. Phillips, J. Scholz, H. J. Wagner, et al.
}

\section{- To cite this version:}

T. Lehrnbecher, A. Attarbaschi, M. Duerken, J. Garbino, B. Gruhn, et al.. Posaconazole salvage treatment in paediatric patients: a multicentre survey. European Journal of Clinical Microbiology and Infectious Diseases, 2010, 29 (8), pp.1043-1045. 10.1007/s10096-010-0957-4 . hal-00594923

\section{HAL Id: hal-00594923 \\ https://hal.science/hal-00594923}

Submitted on 22 May 2011

HAL is a multi-disciplinary open access archive for the deposit and dissemination of scientific research documents, whether they are published or not. The documents may come from teaching and research institutions in France or abroad, or from public or private research centers.
L'archive ouverte pluridisciplinaire HAL, est destinée au dépôt et à la diffusion de documents scientifiques de niveau recherche, publiés ou non, émanant des établissements d'enseignement et de recherche français ou étrangers, des laboratoires publics ou privés. 


\title{
Posaconazole salvage treatment in paediatric patients: a multicentre survey
}

\author{
T. Lehrnbecher - A. Attarbaschi • M. Duerken • J. Garbino • \\ B. Gruhn • U. Kontny • S. Lüer • R. Phillips • J. Scholz • \\ H. J. Wagner • T. Wiesel • A. H. Groll
}

Received: 12 January 2010 /Accepted: 30 April 2010 /Published online: 22 May 2010

(C) Springer-Verlag 2010

\begin{abstract}
While a paediatric dosage has not been defined, posaconazole is occasionally being used in children. We conducted a multicentre retrospective survey and identified 15 patients (median age 10 years [range 3.6-17.5]) who received posaconazole salvage therapy for proven ( 9 patients) or probable (6 patients) invasive fungal infections. Posaconazole was administered for a median of 32 days (range 4-262) at a median dosage of $21 \mathrm{mg} / \mathrm{kg}$ (range 4.833.3). None of the patients discontinued therapy due to
\end{abstract}

The results of this survey were presented in part at the 48th Interscience Conference on Antimicrobial Agents and Chemotherapy, Washington, DC, 2008, and at Trends in Medical Mycology 4, Athens, Greece, 2009.

T. Lehrnbecher $(\bowtie)$

Paediatric Haematology and Oncology, Children's Hospital III,

Johann Wolfgang Goethe University,

Theodor-Stern-Kai 7,

60590 Frankfurt, Germany

e-mail: Thomas.Lehrnbecher@kgu.de

A. Attarbaschi

St. Anna Children's Hospital,

Vienna, Austria

M. Duerken

Children's Hospital of Mannheim,

Mannheim, Germany

J. Garbino

Children's Hospital of Geneva,

Geneva, Switzerland

B. Gruhn

Children's Hospital of Jena,

Jena, Germany

U. Kontny

Children's Hospital of Freiburg,

Freiburg, Germany adverse events, which were mostly mild and observed in 11 patients. Complete or partial responses were observed in 4/ 7 patients with zygomycosis, $3 / 4$ patients with invasive mould infection, $1 / 2$ patients with invasive aspergillosis and $1 / 2$ patients with chronic disseminated candidiasis. We conclude from the data that posaconazole displays favourable safety and tolerance and may be useful for management of individual paediatric patients with invasive infections.

\author{
S. Lüer \\ Children's Hospital of Bern, \\ Bern, Switzerland \\ R. Phillips \\ Children's Hospital of Leeds, \\ Leeds, UK \\ J. Scholz \\ Children's Hospital of Frankfurt-Hoechst, \\ Frankfurt-Hoechst, Germany \\ H. J. Wagner \\ Children's Hospital of Giessen, \\ Giessen, Germany \\ T. Wiesel \\ Children's Hospital of Datteln, \\ Datteln, Germany \\ A. H. Groll \\ Children's Hospital of Münster, \\ Münster, Germany
}


Posaconazole (Noxafil ${ }^{\circledR}$ ) is a novel oral second generation antifungal triazole. Due to its extended activity, posaconazole is widely used in adult patients. While a paediatric dosage has not been defined, posaconazole is occasionally being used in children. Here we report the results of a multicentre retrospective survey on safety and efficacy of posaconazole salvage therapy in children.

Patients eligible for inclusion were $<18$ years of age, had received at least one dosage of posaconazole, and had begun posaconazole therapy prior to the start of the survey. The compound was administered orally at dosages individually determined by the responsible physician until occurrence of intolerance or maximum efficacy on the basis of refractory infection, intolerance of or contraindications to standard therapies, or as best individual therapeutic option. The study was approved by the local ethics committee of Münster, the site of one of the principal investigators (AHG). Invasive fungal infections and response to treatment were classified according to the published EORTC/ MSG criteria and a previous clinical trial of antifungal salvage therapy, respectively $[1,2]$. Clinical adverse events were recorded and graded according to current Common Toxicity Criteria [3]. For statistical comparisons of continuous data, the Mann-Whitney $U$ test was used. A $P$ value of $<0.05$ was considered as significant.

The survey identified 15 patients ( 9 girls, 6 boys; median age 10 years, range 3.6-17.5) who received posaconazole as salvage treatment for proven $(n=9)$ or probable $(n=6)$ invasive fungal infection ( 7 cases with zygomycosis, 4 cases with invasive mold infection, 2 cases with invasive aspergillosis, and 2 cases with chronic disseminated candidiasis) (Table 1). To the best of our knowledge, this is the largest case series of the use of posaconazole in children with proven and probable invasive fungal infection. Most patients had acute leukaemia (10 cases), one patient each suffered from non-Hodgkin lymphoma, aplastic anaemia, solid tumour, soft tissue trauma, chronic granulomatous disease, and diabetes mellitus. Three patients were allogeneic haematopoietic transplant recipients. Nine patients had been exposed to therapeutic dosages of glucocorticosteroids and nine patients had a period of profound neutropenia $(\leq 500 / \mu \mathrm{l})$ within the four weeks prior to the start of posaconazole. All patients had received systemic antifungal therapy prior to treatment with posaconazole (median duration 22 days, range 4-319), in most cases with at least two antifungal agents in combination or sequentially. Six patients received posaconazole as single agent, and nine patients in combination with other systemic antifungal compounds ( 3 cases with amphotericin B, 1 case with caspofungin, and 5 cases with amphotericin B and caspofungin). The median duration of treatment with posaconazole was 32 days (range 4-262); the median daily dosage was $21 \mathrm{mg} / \mathrm{kg}(95 \% \mathrm{CI} 17-25$; range 4.8-33.3). Seven patients received posaconazole at a daily dosage of $600 \mathrm{mg}$ or less ( 6 patients $<13$ years of age), 7 patients at a daily dosage of $800 \mathrm{mg}(3$ patients $<13$ years of age), and one 10-year old at a daily dosage of $1200 \mathrm{mg}$. Plasma levels of posaconazole were not determined in the majority of the patients due to the lack of drug monitoring for posaconazole in most centres.

In none of the patients was treatment with posaconazole discontinued due to clinical or laboratory adverse events (AEs). Irrespective of cause, 22 clinical AEs were observed in 11 patients (73\%). Most AEs (18/22; 8 patients) were of grade I/II; 4/22 recorded AEs were grade III (3 patients). There was no relationship between incidence of AEs and dosage of posaconazole. The most commonly recorded AEs were fever, nausea and/or vomiting, abdominal pain, diarrhea, headache, and skin eruptions. Increases in laboratory hepatic and renal function parameters during therapy were frequent in this population of severely immunocompromised children usually receiving multiple concomitant drugs. However, the mean of the last available values during treatment of liver transaminases, bilirubin, alkaline phosphatase and creatinine were not significantly different from baseline. Overall, both pattern and extent of adverse events observed in this survey do not appear to be substantially different from those reported in adults [4-6].

When analysing efficacy of posaconazole salvage therapy, complete or partial responses were observed in $60 \%$ of the patients: in 4/7 patients with zygomycosis, in $3 / 4$ patients with invasive mold infections, in $1 / 2$ patients with invasive aspergillosis, and in $1 / 2$ patients with CDC (Table 1). Overall survival at 3 months post start of
Table 1 Responses to posaconazole salvage therapy

The numbers of proven/probable invasive fungal infections are given in parenthesis

$C R$ complete response, $P R$ partial response, $S D$ stable disease, $N R$ non-response

\begin{tabular}{llllll}
\hline Infection & \multicolumn{3}{l}{ Number of patients } & & \\
\cline { 2 - 6 } & CR & PR & SD & NR & Survival \\
\hline Invasive zygomycosis (4/3) & 3 & 1 & 1 & 2 & $5 / 7$ \\
Invasive mold infection (4/0) & 2 & 1 & - & 1 & $2 / 4$ \\
Invasive aspergillosis (1/1) & - & 1 & - & 1 & $2 / 2$ \\
Chronic disseminated candidiasis (0/2) & 1 & - & 1 & - & $2 / 2$ \\
All $(9 / 6)$ & 6 & 3 & 2 & 4 & $11 / 15$ \\
\hline
\end{tabular}


treatment was $73 \%(11 / 15)$. Although we recognise that the assessment of efficacy is curtailed by the retrospective nature of this analysis and different indications, the rate of complete or partial responses in our survey was comparable to adults receiving posaconazole salvage therapy [7-10].

In summary, the results of our analysis indicate that posaconazole may be safe and efficacious in the salvage management of invasive fungal infections in immunocompromised children and adolescents. However, the data of ongoing dose-finding pharmacokinetic studies are urgently needed before posaconazole can be recommended in children as salvage treatment for invasive fungal infections.

Conflict of interest TL has received grants from Gilead; he is a consultant to Gilead, Merck, Sharp \& Dohme and Schering-Plough, and served at the speakers' bureau of Astellas, Gilead, Merck, Sharp \& Dohme and Schering-Plough. AHG has received grants from Gilead and Merck, Sharp \& Dohme; he is a consultant to Astellas, Gilead, Merck, Sharp \& Dohme and Schering-Plough, and has served at the speakers' bureau of Astellas, Gilead, Merck, Sharp \& Dohme, Pfizer, Schering-Plough and Zeneus/Cephalon. All other authors have nothing to declare.

Funding None to declare.

\section{References}

1. De Pauw B, Walsh TJ, Donnelly JP, Stevens DA, Edwards JE, Calandra T, Pappas PG, Maertens J, Lortholary O, Kauffman CA, Denning DW, Patterson TF, Maschmeyer G, Bille J, Dismukes WE, Herbrecht R, Hope WW, Kibbler CC, Kullberg BJ, Marr KA, Munoz P, Odds FC, Perfect JR, Restrepo A, Ruhnke M, Segal BH, Sobel JD, Sorrell TC, Viscoli C, Wingard JR, Zaoutis T, Bennett JE (2008) Revised definitions of invasive fungal disease from the European organization for research and treatment of cancer/invasive fungal infections cooperative group and the national institute of allergy and infectious diseases mycoses study group (EORTC/MSG) consensus group. Clin Infect Dis 46:1813-1821
2. Maertens J, Raad I, Petrikkos G, Boogaerts M, Selleslag D, Petersen FB, Sable CA, Kartsonis NA, Ngai A, Taylor A, Patterson TF, Denning DW, Walsh TJ (2004) Efficacy and safety of caspofungin for treatment of invasive aspergillosis in patients refractory to or intolerant of conventional antifungal therapy. Clin Infect Dis 39:1563-1571

3. National Cancer Institution (NCI) Common Toxicity Criteria version 3.0 (2006) Common terminology criteria for adverse events v3.0 (CTCAE). Available at http://ctep.cancer.gov/protocolDevelopment/ electronic applications/docs/ctcaev3.pdf. Accessed October 12, 2009.

4. Cornely OA, Maertens J, Winston DJ, Perfect J, Ullmann AJ, Walsh TJ, Helfgott D, Holowiecki J, Stockelberg D, Goh YT, Petrini M, Hardalo C, Suresh R, Angulo-Gonzalez D (2007) Posaconazole vs. fluconazole or itraconazole prophylaxis in patients with neutropenia. N Engl J Med 356:348-359

5. Langner S, Staber PB, Neumeister P (2008) Posaconazole in the management of refractory invasive fungal infections. Ther Clin Risk Manag 4:747-758

6. Ullmann AJ, Lipton JH, Vesole DH, Chandrasekar P, Langston A, Tarantolo SR, Greinix H, Morais de Azevedo W, Reddy V, Boparai N, Pedicone L, Patino H, Durrant S (2007) Posaconazole or fluconazole for prophylaxis in severe graft-versus-host disease. N Engl J Med 356:335-347

7. Greenberg RN, Mullane K, van Burik JA, Raad I, Abzug MJ, Anstead G, Herbrecht R, Langston A, Marr KA, Schiller G, Schuster M, Wingard JR, Gonzalez CE, Revankar SG, Corcoran G, Kryscio RJ, Hare R (2006) Posaconazole as salvage therapy for zygomycosis. Antimicrob Agents Chemother 50:126-133

8. Raad II, Hanna HA, Boktour M, Jiang Y, Torres HA, Afif C, Kontoyiannis DP, Hachem RY (2008) Novel antifungal agents as salvage therapy for invasive aspergillosis in patients with hematologic malignancies: posaconazole compared with highdose lipid formulations of amphotericin B alone or in combination with caspofungin. Leukemia 22:496-503

9. van Burik JA, Hare RS, Solomon HF, Corrado ML, Kontoyiannis DP (2006) Posaconazole is effective as salvage therapy in zygomycosis: a retrospective summary of 91 cases. Clin Infect Dis 42:e61-e65

10. Walsh TJ, Raad I, Patterson TF, Chandrasekar P, Donowitz GR, Graybill R, Greene RE, Hachem R, Hadley S, Herbrecht R, Langston A, Louie A, Ribaud P, Segal BH, Stevens DA, van Burik JA, White CS, Corcoran G, Gogate J, Krishna G, Pedicone L, Hardalo C, Perfect JR (2007) Treatment of invasive aspergillosis with posaconazole in patients who are refractory to or intolerant of conventional therapy: an externally controlled trial. Clin Infect Dis 44:2-12 